\title{
Reexamining the Religious Policy in the Mongol Empire: A Study of William of Rubruck
}

\begin{abstract}
Junhe Shi ${ }^{1}$
${ }^{1}$ BASIS International School Guangzhou, Guangzhou, Guangdong 510663, China, junhe.shi11784@basisinternational-gz.com

\section{ABSTRACT}

Although the religious situation in the Mongol Empire has been extensively researched, the reasons for the Mongols' tolerant but anti-conversion religious stance toward visiting missionaries remain a mystery. This paper argues the Mongol religious attitude to be one of their political and diplomatic measures to maintain their cultural domination over minority populations, based on a careful examination of William of Rubruck's Account of the Mongols. It fills a gap in the present literature on the Mongol Empire's religious policy.
\end{abstract}

Keywords: Mongol Empire, Christianity, religious toleration, diplomacy

\section{INTRODUCTION \& BACKGROUND}

The so-called "Silk Road," an overland caravan trade route across Afro-Eurasia, acquired its name from the vast quantities of Chinese silk products traded westward along this route. While the name elevates and highlights the Silk Road's commercial significance, the route's value is far beyond what the name could suggest. It was essentially a crucial medium for intellectual and religious exchanges. The Steppe in Central Asia gave rise to nomadic pastoralism along the Silk Road. In the thirteenth century, Genghis Khan, originating from the Steppe, united the Mongol-Turkic nomads and founded the Mongol Empire, which would later become the largest contiguous land empire in world history.

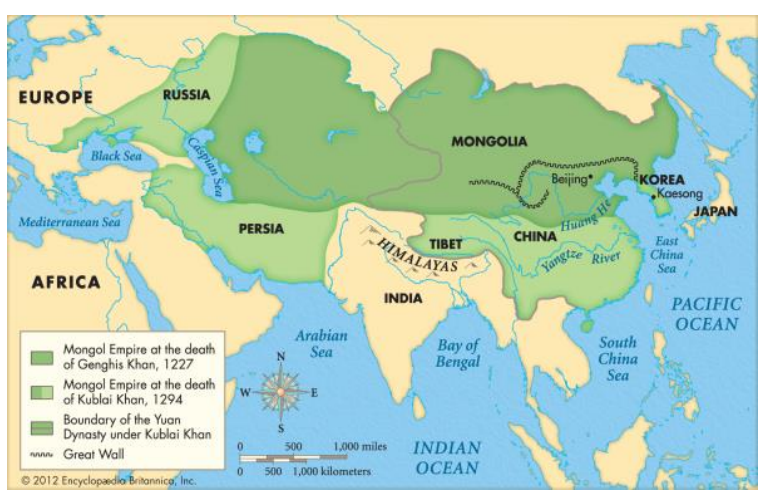

Figure 1Map of the Mongol Empire, Image Source: Britannica

https://www.britannica.com/summary/Decline-of-theMongol-Empire
The territorial triumph of the Mongol Empire placed most of the Silk Road under Mongol occupation. With its vast cross-continental territory, there was considerable diversity in culture in the Mongol Empire. Besides Shamanism, the predominant religion, there was also a substantial minority of Christians, Buddhists, Muslims, and Taoists[1, 2]. This paper explores the cultural exchanges between the minority visitors and missionaries and the majority Mongols, focusing on the place of Christianity in the Mongol Empire. This paper substantially builds its claims upon William of Rubruck's Account of the Mongols.

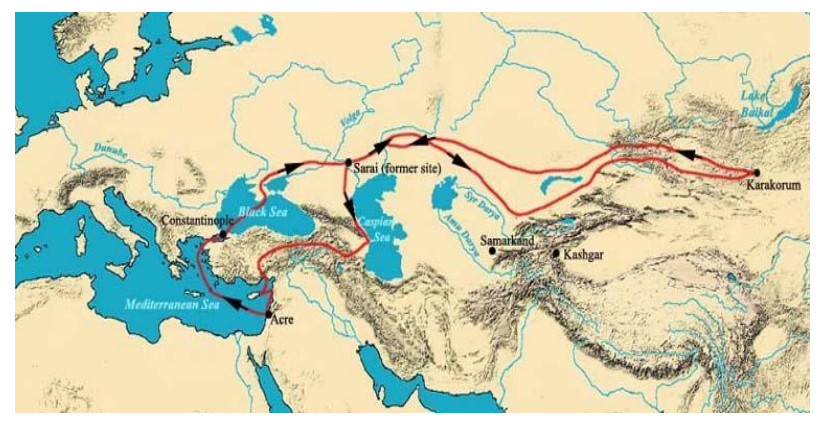

Figure 2 William of Rubruck's journey, Image Source: Wikipedia

https://en.wikipedia.org/wiki/William_of_Rubruck

William of Rubruck was a Franciscan missionary and explorer who also accompanied King Louis IX of France on the Seventh Crusade against Muslims. Louis IX suffered a defeat, so he set Rubruck out on a missionary journey to the Mongol Empire to convert the Mongols into Christianity. On Rubruck's return, he compiled his 
conversations with the Mongols and discoveries, including geographical observations and cultural peculiarities of the Mongol Empire, into a report for Louis IX. Thus, The Account could offer plentiful, detailed relevant information regarding Mongol daily routines and cultural customs.

This paper claims that the Mongol Empire facilitated the spread of Christianity across Euroasia with a tolerant attitude towards incoming missionaries but has refused mainstream conversions and dissenting practices of Christianity to sustain their dominance. This paper first establishes that the Mongols were highly tolerant towards most religions and maintained friendly terms with monks, missionaries, and envoys visiting the Mongol Empire. Then, this paper identifies and discusses another aspect of the Mongols' attitude towards visitors: arrogance. Finally, this paper explores several cultural conflicts between the Christians and the Mongols, explicated in Rubruck's The Account, and concludes that the Mongols' mixed attitudes towards Christianity indicate their political and diplomatic strategies that aimed to maintain Mongol cultural dominance over the minorities[3].

\section{TOLERANCE}

The general situation of the various religions in the Mongol Empire has been explored and portrayed in numerous studies. Professor Peter Zieme, an expert in Turkish studies, modified the term "pax mongolica" into "pax religiosa" to describe the peaceful and tolerant religious environment in the Mongol Empire[4-6]. This trend is evident in The Account, where Rubruck recorded his observations and experience at Mangu Chan's ordu.

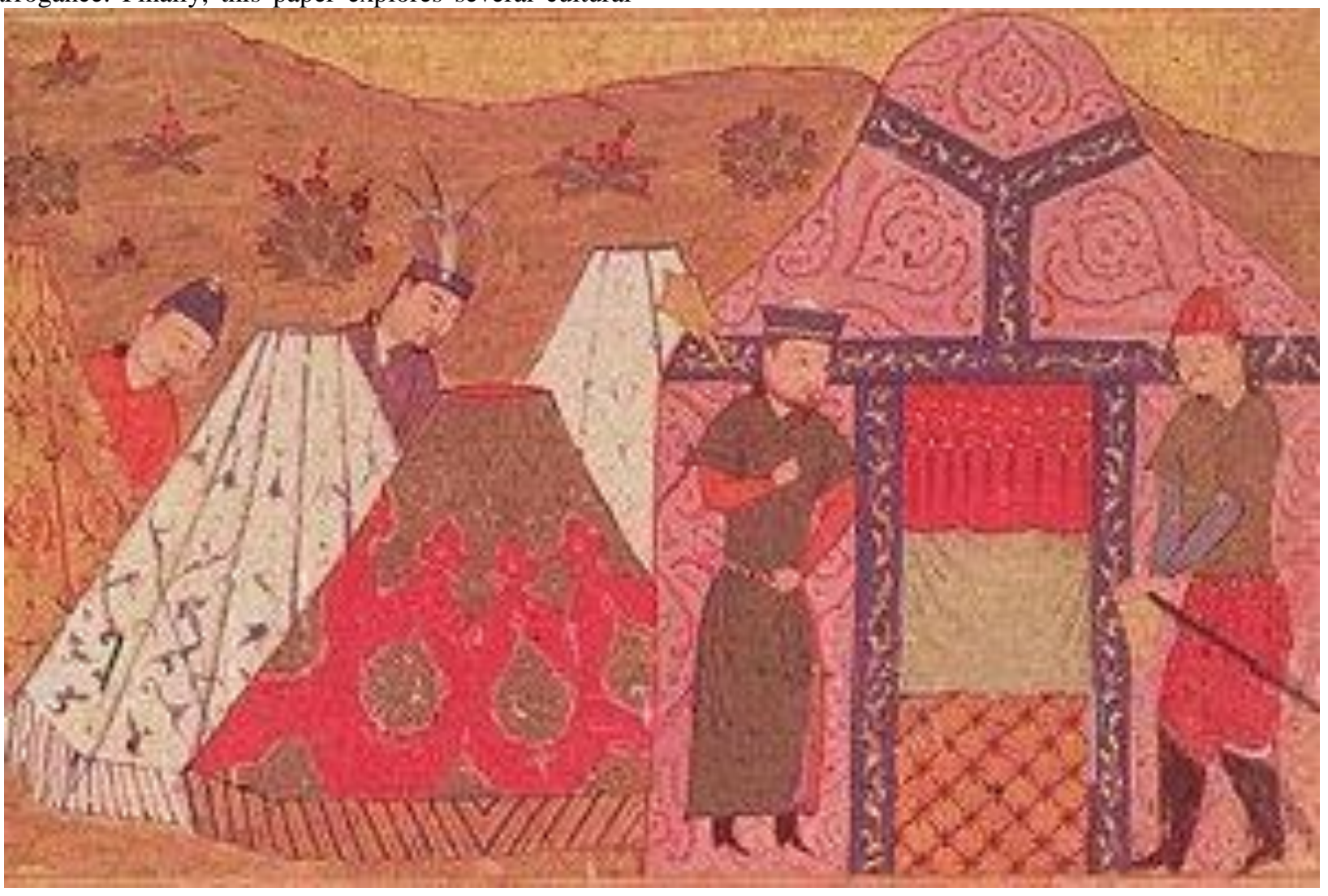

Figure 3 An ordu, Image Source: Wikipedia https://en.wikipedia.org/wiki/Orda_(organization)

Ordu is a term that Rubruck used to describe Mongol tent and the royal court. In the ordu, Rubruck saw Buddhists, Nestorians, Saracens, and Iugurs - a diversified group of visitors — being treated friendly by the Mongols[3]. Mangu Chan also offered Rubruck a lodging, and Rubruck commented:

"They had supplied us with couches and bed covering, and brought us fuel... Daily they gave us a bowl full of millet and a quart of millet mead, and they borrowed for us a kettle and a tripod to cook our meat; and when it was cooked we boiled the millet in the pot liquor" [3].

Evidently, Mangu Chan provided suitable housing and dining arrangements for visitors like Rubruck. Not only was Mangu Chan welcoming, but he also readily accepted Rubruck's teachings of the Christian faith. As previously mentioned, Rubruck visited Mangu Chan primarily in order to convert the Great Khan to Christianity so that the Mongols could perhaps aid Louis IX in the next Crusade. Although Mangu Chan never directly promised to convert, he still willingly accepted 
Rubruck's teachings, visited Rubruck's oratory in his lodging, and asked Rubruck about the pictures on the Bible[3]. Mangu Chan's tolerant policy allowed each minority religion to thrive in the Mongol Empire, but none achieved dominance. As for Christianity, the Nestorians, the Eastern Christians, only constituted a substantial minority in the Mongol Empire.

While the current literature commonly agrees that the Mongols tolerated the minority religions and rejected mainstream conversions, it lacks an explicative clarification of the motive for this policy. Timothy May, a specialist in the Mongol Empire, relates this policy to the Mongol's imperial theory that power was given as a mandate by heaven[7, 8]. That is, the Mongols regarded all other religions as means to maintain that power and rejected mainstream conversions because of their belief that the heavens ordained their faiths[8]. This essay will analyze this policy from a distinctive political perspective.

\section{ARROGANCE}

While it seemed that the Mongols welcomed missionaries, Rubruck's The Account sheds light upon another aspect of the Mongols' frame of mind: arrogance and opinionatedness. During Rubruck's conversation with Mangu Chan, even though the former elucidated his purpose of visiting, the latter still thought that Rubruck, like many other envoys, was sent by his lord to "make peace with them"[3]. In fact, many of the Mongols whom Rubruck met obstinately believed that Rubruck, who more than once clarified that he was not an envoy, had traveled to the Empire to negotiate with them[8,9]. This arrogant attitude, despite the Mongol's tolerance of
Christianity, was much to Rubruck's indignation. For two times in The Account, Rubruck remarked that "[the Mongols] are already so puffed up in their pride" and that they believed that "the whole world must want to make peace with them" $[3,10]$. The Mongol Empire was indeed a peculiar environment for Rubruck. Rubruck was a Franciscan missionary in France, a country of Christendom. In the Mongol Empire, a diversity of religions allowed Christianity to spread while also prevented any minority religions from dominance. Rubruck's perspective, thus, presents a cultural clash between the Mongols and the Christians. In response to Mangu Chan's arrogance, Rubruck replied, with some displeasure: "If you without motive should want to wage war against [the French King], or his people, we trust that God, who is just, would aid them"[3]. The cultural conflicts that Rubruck faced in the Mongol Empire were beyond conversational, and the imposition of Mongol customs upon outsiders and minority groups was arguably a political tool.

\section{ACCULTURATION OF CHRISTIANITY IN THE MONGOL EMPIRE}

Throughout Rubruck's journey, he has been offered cosmos, or fermented mare's milk, by almost every Mongol he met.

When he saw other Christians in the Mongol Empire drinking cosmos, Rubruck noted that if they "wish to follow strictly their religion, drink it not," but if they drink it, they "[considered] themselves to be no longer Christians" and had "denied the faith of Christ"[3] Rubruck refused to drink cosmos before the liquor he brought from France ran out.

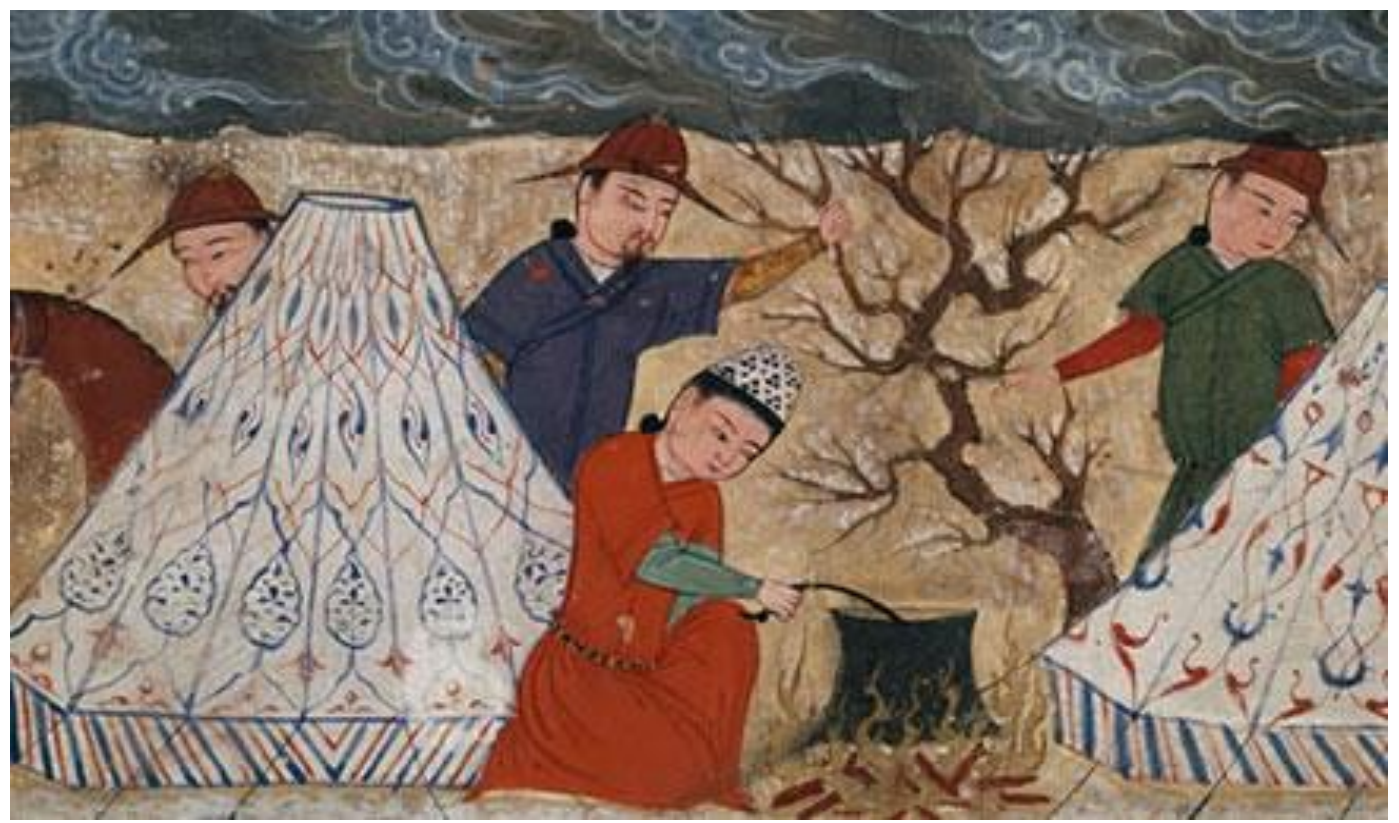

Figure 4 The making of mare's milk, Image Source: Asia for Educators http://afe.easia.columbia.edu/mongols/pastoral/pastoral7.htm 
While Rubruck refused to conform, other Christians and Nestorians adopted the Mongol customs. Rubruck encountered a person "who had a little cross in ink on his hand," and, after talking to him, Rubruck realized that person had omitted some doctrinal practices of Christianity[3]. In fact, the practice of Nestorian, the Christianity of the East, was initially somewhat different from that practiced in the West. Franciscans tended to regard Nestorianism as heretical for its beliefs about the nature of Jesus. In Rubruck's The Account, most Nestorians have acculturated to the Mongol customs. For the conflicting Christian and Mongol practices, many Nestorians have abandoned the former and adopted the latter under the surrounding cultural influence, Even for a devout Franciscan like Rubruck, he too had to conform to the Mongol customs. When he was offered cosmos again in Mangu Chan's ordu, he said: "My lord, we are not men who seek to satisfy our fancies about drinks; whatever pleases you will suit us"[3].

Another conflict also appeared when the Khans asked Rubruck to bend his knees before them. Rubruck viewed himself as a "priest given to the service of God," and for the glory of God, noblemen in France do not "allow priests to bend the knees before them"[3]. Nevertheless, after he sang "praises to God who has brought [them] here in safety from so far," Rubruck still bent down his knees at Mangu Chan's insistence; Rubruck also requested that "nothing be required of [them] contrary to the worship and glory of God" $[3,10]$.

Although the Mongols tolerated numerous religions in their territory, they have forcibly imposed Mongol customs upon the minority religions. Under these impositions, the minority religions acculturated to Mongol customs, a notable example being Nestorianism. The Mongols utilized their mixed religious policy as a political strategy to control the minority religions and prevent any from dominating the mainstream society. As a result of their forcible imposition of Mongol customs, Christians and Nestorians who lived in the Mongol Empire had to obey their orders and relinquish the dissenting practices of their religion. With internal cultural conformity among the Mongols and the minority, it was unlikely that any religions would acquire political dominance in the government due to the diversity of beliefs that the Mongols tolerated.

\section{CONCLUSION}

Although numerous Christian missionaries like Rubruck had traveled to the Mongol Empire to proselytize the Mongols, Christians remained a minority. With toleration, various religions were able to thrive in the Mongol Empire, but none could dominate over others due to both the diversity and conflicts among different religions, such as Christianity and Islam. With acculturation, the diversity of beliefs converged and acculturated to Mongol customs in the Empire. This paper sheds light on a politically strategic aspect of the somewhat well-known Mongol religious policy towards outside religions. With a specific focus on Rubruck's The Account, this paper investigates and comments on the specific culturally conflicting practices between Christians and the Mongols, demonstrating how dissenting practices were forced to conform to the Mongol customs.

\section{REFERENCES}

[1] Zieme, Peter. "Religions of the Turks in the PreIslamic Period." In Turks: A Journey of a Thousand Years, 600-1600, edited by David J. Roxburgh, 3237. London, 2005. Digital file.

[2] Kitagawa, S. (1989) "Triangular Structure of the Christians, the Muslims and the Mongols.” pp. 11221.

[3] Rubruck, William. William of Rubruck's Account of the Mongols, 1-66. N.p., 1254.

https://depts.washington.edu/silkroad/texts/rubruck. html

[4] Allsen, T. "The Yuan Dynasty and the Uighurs of Turfan in the $13^{\text {th }}$ century," in Rossabi (ed.), China among Equals, pp. 243-50.

[5] Chen, Y. (1996) Western and Central Asians in China under the Mongols: Their Transformation into Chinese. Los Angeles.

[6] Zieme, Peter. "Notes on a Bilingual Prayer Book from Bulayik," in D. Winkler and Li Tang (eds), Hidden Treasures and Intercultural Encounters. Studies on East Syriac Christianity in China and Central Asia, pp. $167-80$

[7] Zieme, Peter. "Notes on the Religions in the Mongol Empire." In Islam and Tibet: Interactions along the Musk Routes, edited by Anna Akasoy, Charles Burnett, and Ronit Yoelitlalim, 177-88. Abingdon, Oxon: Routledge, Taylor and Francis Group, 2011. Digital file.

[8] May, Timothy. "Attitudes towards Conversion among the Elite in the Mongol Empire." Asian Studies on the Pacific Coast, 2002. Accessed July 3, 2021. https://web.archive.org/web/20061107101245/http:/ /mcel.pacificu.edu/easpac/2003/may.php3\#1.

[9] Juvaini, Ata Malik. (1997) Genghis Khan: The History of the World Conqueror, translated by J.A Boyle. Manchester University Press, p.67.

[10] Khazanov, Anatoly. (1994) "The Spread of World Religions in Medieval Nomadic Societies of the Eurasian Steppes." Toronto Studies in Central and Inner Asia, p.15. 